\title{
Highly Sensitive and Selective Hydrogen Gas Sensor Using the Mesoporous $\mathrm{SnO}_{2}$ Modified Layers
}

\author{
Niuzi Xue ${ }^{1}$, Qinyi Zhang ${ }^{1, *}$, Shunping Zhang ${ }^{2}$, Pan Zong ${ }^{1}$ and Feng Yang ${ }^{1}$ \\ 1 School of Material Science and Engineering, Wuhan University of Technology, Wuhan 430070, China; \\ xueniu@whut.edu.cn (N.X.); Mrzongpan@163.com (P.Z.); yfeng047@163.com (F.Y.) \\ 2 Department of Materials Science and Engineering, Huazhong University of Science and Technology, \\ Wuhan 430074, China; pszhang@mail.hust.edu.cn \\ * Correspondence: zhqy@whut.edu.cn; Tel.: +86-181-6266-2798
}

Received: 7 September 2017; Accepted: 10 October 2017; Published: 14 October 2017

\begin{abstract}
It is important to improve the sensitivities and selectivities of metal oxide semiconductor (MOS) gas sensors when they are used to monitor the state of hydrogen in aerospace industry and electronic field. In this paper, the ordered mesoporous $\mathrm{SnO}_{2}\left(\mathrm{~m}-\mathrm{SnO}_{2}\right)$ powders were prepared by sol-gel method, and the morphology and structure were characterized by $\mathrm{X}$-ray diffraction analysis (XRD), transmission electron microscope (TEM) and Brunauer-Emmett-Teller (BET). The gas sensors were fabricated using $\mathrm{m}-\mathrm{SnO}_{2}$ as the modified layers on the surface of commercial $\mathrm{SnO}_{2}\left(\mathrm{c}-\mathrm{SnO}_{2}\right)$ by screen printing technology, and tested for gas sensing towards ethanol, benzene and hydrogen with operating temperatures ranging from $200{ }^{\circ} \mathrm{C}$ to $400{ }^{\circ} \mathrm{C}$. Higher sensitivity was achieved by using the modified $\mathrm{m}-\mathrm{SnO}_{2}$ layers on the $\mathrm{c}-\mathrm{SnO}_{2}$ gas sensor, and it was found that the $\mathrm{S}(\mathrm{c} / \mathrm{m} 2)$ sensor exhibited the highest response $(\mathrm{Ra} / \mathrm{Rg}=22.2)$ to $1000 \mathrm{ppm}$ hydrogen at $400{ }^{\circ} \mathrm{C}$. In this paper, the mechanism of the sensitivity and selectivity improvement of the gas sensors is also discussed.
\end{abstract}

Keywords: gas sensor; mesoporous $\mathrm{SnO}_{2}$; hydrogen; sensitivity; selectivity

\section{Introduction}

As one of the most important clean energies, $\mathrm{H}_{2}$ is widely used in various fields such as fuel cell vehicles, aerospace industry, petrochemical industry, and electronic field [1-3]. In consideration of the leakage in the applications of $\mathrm{H}_{2}$ whose explosive limit is very low, it is essential to monitor the state of hydrogen. Gas sensor is one of the most effective detectors $[4,5]$.

Great emphasis is being given to metal oxide semiconductors (MOS), including $\mathrm{ZnO}$ [6], $\mathrm{WO}_{3}$ [7], $\mathrm{TiO}_{2}$ [8], $\mathrm{In}_{2} \mathrm{O}_{3}$ [9] and $\mathrm{SnO}_{2}$ [10], as gas sensing materials for a long time. Among various MOS gas sensors, $\mathrm{SnO}_{2}$-based gas sensors are widely used because of their low cost, high sensitivity and long-term stability [11]. However, poor selectivity to various gases restricts their applications. Gas sensing performances of $\mathrm{SnO}_{2}$, especially the selectivity to $\mathrm{H}_{2}$, can be improved by applying doping [12-14], catalyst [15-17], filtering membranes [18-20], etc. For example, Inyawilert et al. studied the films of $\mathrm{SnO}_{2}$ nanoparticles doped with 0.1 2 wt.\% rhodium (Rh). It showed that the Rh-doped $\mathrm{SnO}_{2}$ sensor presented high $\mathrm{H}_{2}$ selectivity against $\mathrm{NO}_{2}, \mathrm{SO}_{2}, \mathrm{C}_{2} \mathrm{H}_{4}, \mathrm{C}_{3} \mathrm{H}_{6} \mathrm{O}, \mathrm{CH}_{4}, \mathrm{H}_{2} \mathrm{~S}$ and $\mathrm{CO}$ [13]. Liewhiran et al. reported that Pd-catalyzed $\mathrm{SnO}_{2}$ sensor (0.2 wt.\% Pd/ $\mathrm{SnO}_{2}, 10 \mu \mathrm{m}$ in thickness) showed ultra-high response to $\mathrm{H}_{2}$ [15]. It was found in the work of Tournier et al. that $\mathrm{SiO}_{2}$ filter film deposited on the $\mathrm{SnO}_{2}$ film is highly selective to hydrogen [18]. Filtering membranes such as $\mathrm{SiO}_{2}$, $\mathrm{Al}_{2} \mathrm{O}_{3}, \mathrm{Fe}_{2} \mathrm{O}_{3}$, etc. work as molecular sieves. They are useful to improve the selectivity of gas sensors.

Gas sensing performances of $\mathrm{SnO}_{2}$ gas sensors can be highly improved by using mesoporous material because of its high specific surface area (SSA) [21]. Japanese researchers fabricated nano-SnO powders coated by mesoporous $\mathrm{SnO}_{2}\left(\mathrm{~m}-\mathrm{SnO}_{2}\right)$, and this kind of $\mathrm{SnO}_{2}$ films highly increased the responses to $\mathrm{H}_{2}$ [21]. It was found in the work of Pijolat et al. that thin $\mathrm{SiO}_{2}$ films deposited on the 
$\mathrm{SnO}_{2}$ thick films could improve the selectivity to $\mathrm{H}_{2}$ [22]. Dhawale et al. synthesized mesoporous $\mathrm{ZnO}$ thin films which showed high selectivity towards liquefied petroleum [23]. The aim of the present study was to improve the selectivity and sensitivity simultaneously in hydrogen detection. The uses of such mesoporous materials enable enhancement of the adsorption and reaction of test gas because of the high specific surface area. On the other hand, mesoporous materials are potential molecular sieves for gas sensors to improve their selectivity because of the mesoporous structure.

In this paper, the $\mathrm{m}-\mathrm{SnO}_{2}$ powders were synthesized with a simple and low cost sol-gel method. The sensors were fabricated using commercial $\mathrm{SnO}_{2}\left(\mathrm{c}-\mathrm{SnO}_{2}\right)$ films as the basic layer and the $\mathrm{m}-\mathrm{SnO}_{2}$ films as the modified layers by screen printing method. Their sensing performances were tested with hydrogen, ethanol and benzene. The relationships between selectivity and the thickness of the films were studied. The present study aims to develop a low cost and highly sensitive and selective hydrogen gas sensor.

\section{Materials and Methods}

\subsection{Preparation of $m-\mathrm{SnO}_{2}$ Powders}

Employing $\mathrm{Na}_{2} \mathrm{SnO}_{3} \cdot 4 \mathrm{H}_{2} \mathrm{O}$ as the $\mathrm{Sn}$ source, n-cetylpyridinium chloride $\left(\mathrm{C}_{16} \mathrm{PyCl}\right)$ as the template and trimethylbenzene $\left(\mathrm{C}_{6} \mathrm{H}_{3}\left(\mathrm{CH}_{3}\right)_{3}\right)$ as the surfactant, $\mathrm{m}-\mathrm{SnO}_{2}$ powders were prepared in a similar way to that reported previously [21]. The typical preparation manner was as follows. $\mathrm{C}_{16} \mathrm{PyCl}$ was added to the deionized water at $2.6 \mathrm{wt} . \%$, while $\mathrm{Na}_{2} \mathrm{SnO}_{3} \cdot 4 \mathrm{H}_{2} \mathrm{O}$ was dissolved in the deionized water at $3.6 \mathrm{wt} . \%$. In this case, $\mathrm{Na}_{2} \mathrm{SnO}_{3} \cdot 4 \mathrm{H}_{2} \mathrm{O}$ aqueous was mixed with the $\mathrm{C}_{16} \mathrm{PyCl}$ solution at a molar ratio $\left[\mathrm{C}_{16} \mathrm{PyCl}\right] /\left[\mathrm{Na}_{2} \mathrm{SnO}_{3} \cdot 4 \mathrm{H}_{2} \mathrm{O}\right]=2.0$. Then, trimethylbenzene was added to the solution at a molar ratio $\left[\mathrm{C}_{6} \mathrm{H}_{3}\left(\mathrm{CH}_{3}\right)_{3}\right] /\left[\mathrm{Na}_{2} \mathrm{SnO}_{3} \cdot 4 \mathrm{H}_{2} \mathrm{O}\right]=2.5$. The $\mathrm{pH}$ of the mixture was then adjusted to 10 with an aqueous $35 \mathrm{wt} . \% \mathrm{HCl}$ solution. The resultant emulsion solution was aged for 2 days at $25{ }^{\circ} \mathrm{C}$. After suction filtration with deionized water and drying, the resultant solid products were treated with a $0.1 \mathrm{M}$ aqueous phosphoric acid (PA) solution for $2 \mathrm{~h}$ with magnetic stirrers. Then, it was filtered off, washed and dried at $60^{\circ} \mathrm{C}$ for $12 \mathrm{~h}$. Eventually, the solid was calcined at $600{ }^{\circ} \mathrm{C}$ for $5 \mathrm{~h}$ in air. After calcination, the powders were subjected to mechanical grinding with an agate mortar.

The crystal phases of the $\mathrm{m}-\mathrm{SnO}_{2}$ powders were characterized via X-ray diffraction analysis $(\mathrm{XRD}$, D8 Adwance, Bruker, Karlsruhe, Germany). The specific surface area and pore size distribution were measured by the Brunauer-Emmett-Teller (BET) method using a $\mathrm{N}_{2}$ adsorption isotherm (BET, ASAP 2020, Micromeritics, Norcross, GA, USA). Morphology of the $\mathrm{m}-\mathrm{SnO}_{2}$ powders was observed by a transmission electron microscope (TEM, JEM2100F STEM/EDS, JEOL, Tokyo, Japan) and the morphology of the commercial $\mathrm{SnO}_{2}\left(\mathrm{c}-\mathrm{SnO}_{2}\right)$ powders was observed by a scanning electron microscope (SEM, JSM-IT300, JEOL, Tokyo, Japan).

\subsection{Fabrication of $\mathrm{SnO}_{2}$ Sensors}

Pastes of the $\mathrm{c}-\mathrm{SnO}_{2}$ powders and the as-prepared $\mathrm{m}-\mathrm{SnO}_{2}$ powders were applied on a substrate $(30 \mathrm{~mm} \times 6 \mathrm{~mm} \times 0.625 \mathrm{~mm})$, on which interdigitated Pt electrodes had been printed with mechanically automated screen printing technology, as shown in Figure 1.

The thick film gas sensors were fabricated using screen printing technology. For the first layer, the $\mathrm{c}-\mathrm{SnO}_{2}$ powders were mixed with the printing oil (YY-1010, Wuhan Huachuang Ruike Tech. Co. LTD, Wuhan, China) at the mass ratio of $1: 1$ as the paste. Furthermore, to improve the stability of the gas sensors, the frit of $\mathrm{PbO}, \mathrm{B}_{2} \mathrm{O}_{3}$, and $\mathrm{SiO}_{2}$ (mass ratio $[\mathrm{PbO}] /\left[\mathrm{B}_{2} \mathrm{O}_{3}\right] /\left[\mathrm{SiO}_{2}\right]=45 / 35 / 20$ ) was added into the $\mathrm{c}-\mathrm{SnO}_{2}$ powders at the level of $2 \mathrm{wt} . \%$. The substrates were treated with drying at room temperature for $10 \mathrm{~min}$ and $50{ }^{\circ} \mathrm{C}$ for $1 \mathrm{~h}$ when the pastes were printed on them. For modified layer, the paste was mixed with the $\mathrm{m}-\mathrm{SnO}_{2}$ powders and the printing oil at the same mass ratio of 1:1. To prepare more modified layers, simply repeat the printing step above. Eventually, the gas sensors were dried at $50^{\circ} \mathrm{C}$ for $1 \mathrm{~h}$ and calcined at $650{ }^{\circ} \mathrm{C}$ for $2 \mathrm{~h}$. The different fabricated gas sensors are listed in Table 1. 


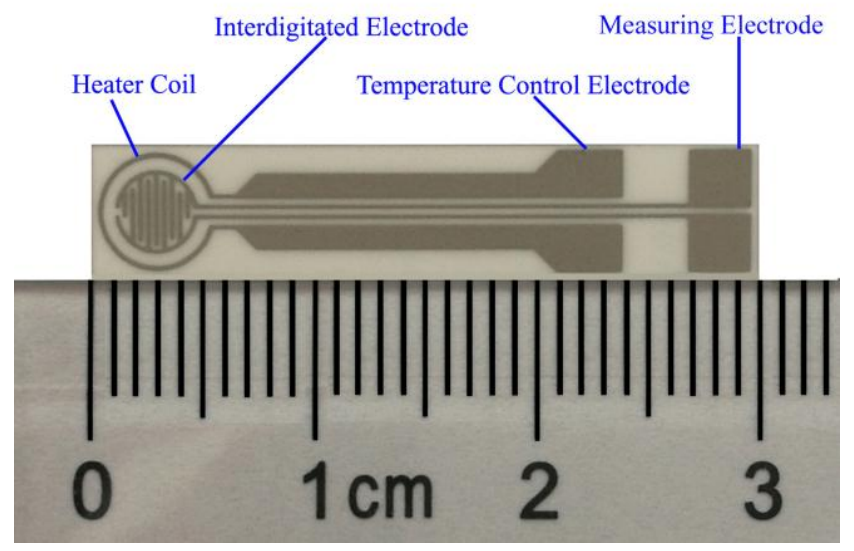

Figure 1. The substrate structure of the gas sensor.

Table 1. The structure of the gas sensors.

\begin{tabular}{|c|c|c|c|}
\hline \multirow{2}{*}{ Sample } & Basic Layer & Modified Layer & \multirow{2}{*}{ Description } \\
\hline & Material & Material & \\
\hline $\mathrm{S}(\mathrm{c})$ & $\mathrm{c}-\mathrm{SnO}_{2}$ & / & one layer of c-SnO 2 \\
\hline $\mathrm{S}(\mathrm{m})$ & $\mathrm{m}-\mathrm{SnO}_{2}$ & / & one layer of $\mathrm{m}-\mathrm{SnO}_{2}$ \\
\hline $\mathrm{S}(\mathrm{c} / \mathrm{m} 1)$ & $\mathrm{c}-\mathrm{SnO}_{2}$ & $\mathrm{~m}-\mathrm{SnO}_{2}$ & one layer of c-SnO ${ }_{2}$ and one layer of $\mathrm{m}-\mathrm{SnO}_{2}$ \\
\hline $\mathrm{S}(\mathrm{c} / \mathrm{m} 2)$ & $\mathrm{c}-\mathrm{SnO}_{2}$ & $\mathrm{~m}-\mathrm{SnO}_{2}$ & one layer of c-SnO ${ }_{2}$ and two layers of $\mathrm{m}-\mathrm{SnO}_{2}$ \\
\hline $\mathrm{S}(\mathrm{c} / \mathrm{m} 3)$ & $\mathrm{c}-\mathrm{SnO}_{2}$ & $\mathrm{~m}-\mathrm{SnO}_{2}$ & one layer of c- $\mathrm{SnO}_{2}$ and three layers of $\mathrm{m}-\mathrm{SnO}_{2}$ \\
\hline
\end{tabular}

The surface morphology of the prepared gas sensors was observed by a scanning electron microscope (SEM, Zeiss Utral Plus, Cari Zeiss AG, Jena, Germany). The cross-sections of the different $\mathrm{SnO}_{2}$ films were observed by a scanning electron microscope (SEM, S-4800, HITACHI, Tokyo, Japan).

\subsection{Measurement of Sensing Performance}

The gas sensors were measured by a commercial SD-101 gas sensing performance testing device (Wuhan Huachuang Ruike Tech. Co. LTD, Wuhan, China) which can be used with four gas sensors to test their gas sensing performance simultaneously (Figure 2). The operating temperature can be controlled via adjusting the power of the heater coil by a microprocessor. The operating temperature of the gas sensors is in the range of room temperature to $450{ }^{\circ} \mathrm{C}$.

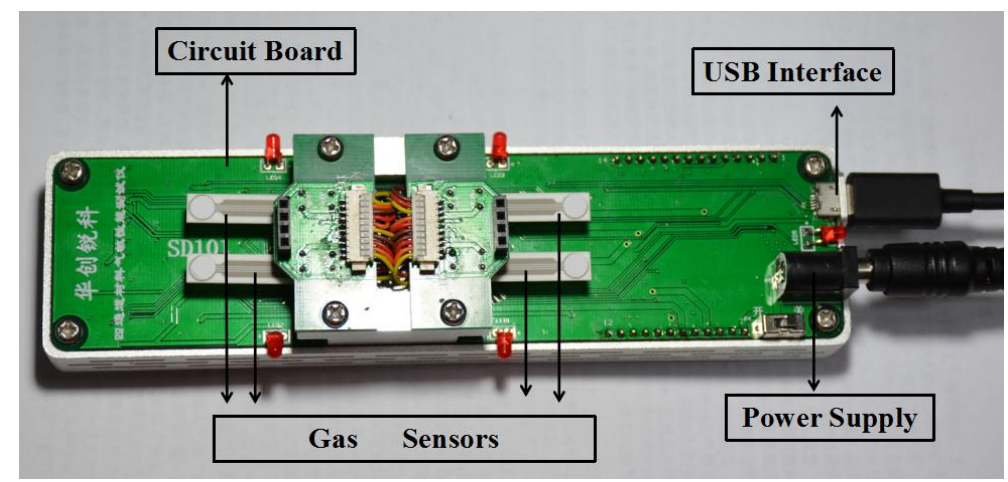

Figure 2. The SD-101 gas sensing performance testing device.

The prepared gas sensors were measured to sense $1000 \mathrm{ppm}_{2}$ with dynamic method and $10 \mathrm{ppm}$ ethanol and benzene with static method at the temperature of $200{ }^{\circ} \mathrm{C}, 250{ }^{\circ} \mathrm{C}, 300{ }^{\circ} \mathrm{C}, 350{ }^{\circ} \mathrm{C}$ and $400{ }^{\circ} \mathrm{C}$. In the process of dynamic measurement, the SD-101 gas sensing performance testing device 
was placed in a cylinder of $60 \mathrm{~mm}$ in diameter, which is made of polymethyl methacrylate (PMMA). The testing gas flowchart is shown in Figure 3.

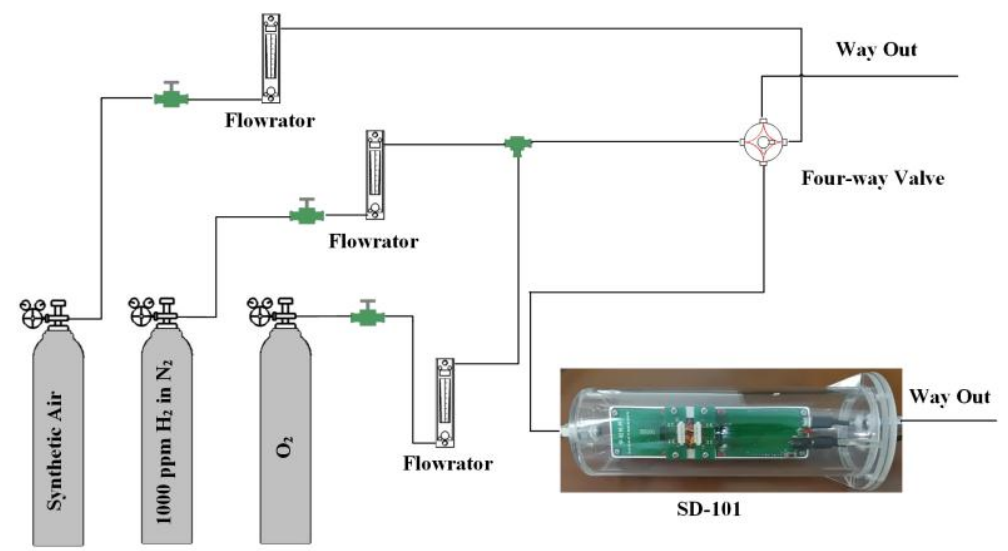

Figure 3. Gas sensing testing device.

The synthetic air, whose flow rate was set as $250 \mathrm{~mL} / \mathrm{min}$, consisted of $\mathrm{N}_{2}$ and $\mathrm{O}_{2}$ at the volume ratio of 4:1. To match with the synthetic air, the volume ratio of the $1000 \mathrm{ppm}_{2}$ in $\mathrm{N}_{2}$ and $\mathrm{O}_{2}$ was also set as 4:1 with the flow rate of $200 \mathrm{~mL} / \mathrm{min}$ and $50 \mathrm{~mL} / \mathrm{min}$, respectively. During the testing process, the synthetic air was replenished by adjusting the four-way valve. The four-way valve is first turned to let the hydrogen in when the response was stabilized. When the response was stabilized, the four-way valve is turned to lead the synthetic air to go through the cylinder until the sensors recover

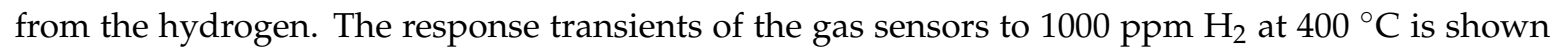
in Figure 4. It is obvious that all the gas sensors exhibit stable and quick response. In the process of dynamic measurement, the SD-101 gas sensing performance testing device was placed in a cubic evaporated cavity for $50 \mathrm{~L}$. During the testing process, the corresponding quantities of the organic solution (ethanol and benzene) were injected by a micro-injector on a heating panel in the evaporated cavity, when the gas sensors responses to air stabilized. When the response to the test gas stabilized, the cubic testing cavity was opened for recovery.

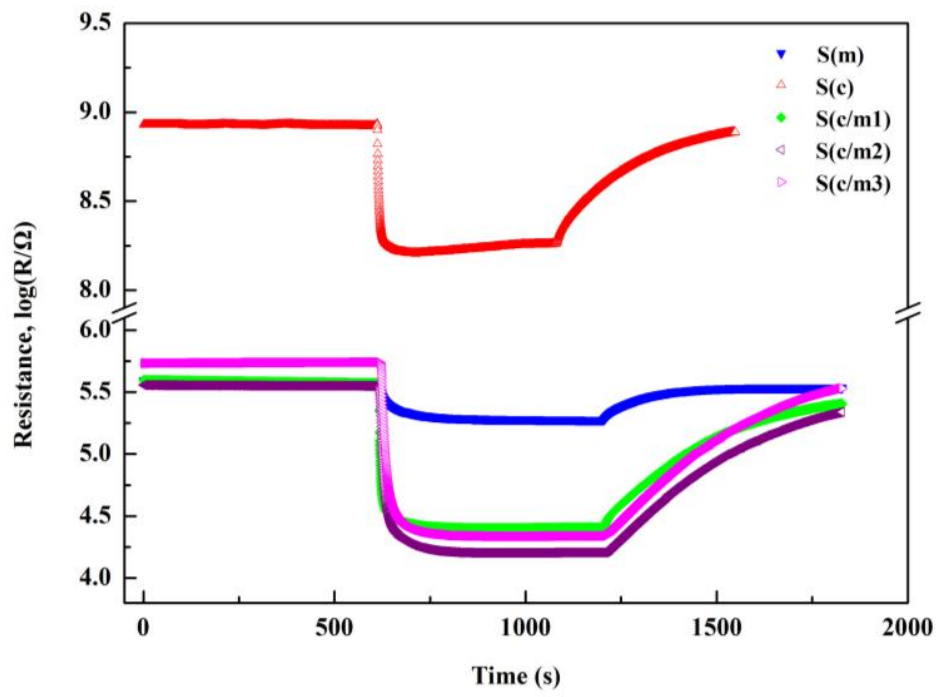

Figure 4. Response transients of the gas sensors to $1000 \mathrm{ppm} \mathrm{H}_{2}$ at $400{ }^{\circ} \mathrm{C}$.

The response is defined as $\mathrm{Ra} / \mathrm{Rg}$, where $\mathrm{Ra}$ and $\mathrm{Rg}$ are the sensor resistances in air and in the test gas, respectively. The response time is generally defined as the time necessary for achieving a 
$90 \%$ resistance change to the steady-state value. The recovery time is defined as the time for sensor resistance to reach $90 \%$ of air resistance.

\section{Results and Discussion}

\subsection{Characterization of the c-SnO $\mathrm{O}_{2}$ Powders and the $\mathrm{m}-\mathrm{SnO} \mathrm{O}_{2}$ Powders}

Figure 5 shows XRD patterns of the $\mathrm{c}-\mathrm{SnO}_{2}$ powders (Figure $5 \mathrm{a}$ ) and the $\mathrm{m}-\mathrm{SnO}_{2}$ powders (Figure $5 b$ ). The c-SnO 2 powders have peaks corresponding to the $\mathrm{SnO}_{2}$ crystalline phase (PDF 41-1445). This implies that the c-SnO 2 powders are well-crystallized, and have a tetragonal $\mathrm{SnO}_{2}$ phase. The crystallite size of the c-SnO ${ }_{2}$, calculated by Scherrer's equation (Jade), is about $65.5 \mathrm{~nm}$. It is also confirmed by the SEM image (Figure 6). The XRD pattern of the $\mathrm{m}-\mathrm{SnO}_{2}$ powders (Figure $5 \mathrm{~b}$ ) shows that they have some main peaks corresponding to $\mathrm{SnO}_{2}$ crystalline phase. It reveals that the prepared $\mathrm{m}-\mathrm{SnO}_{2}$ powders have low crystallinity. In addition, the ordered mesoporous structure is confirmed clearly by the TEM observation of the $\mathrm{m}-\mathrm{SnO}_{2}$ powders in Figure 7 . The pore size distribution and the specific surface area of the $\mathrm{m}-\mathrm{SnO}_{2}$ powders are shown in Figure 8. It is clear that the $\mathrm{m}-\mathrm{SnO}_{2}$ powders show a large SSA of $262.30 \mathrm{~m}^{2} / \mathrm{g}$ with a small pore size of $2.6 \mathrm{~nm}$.
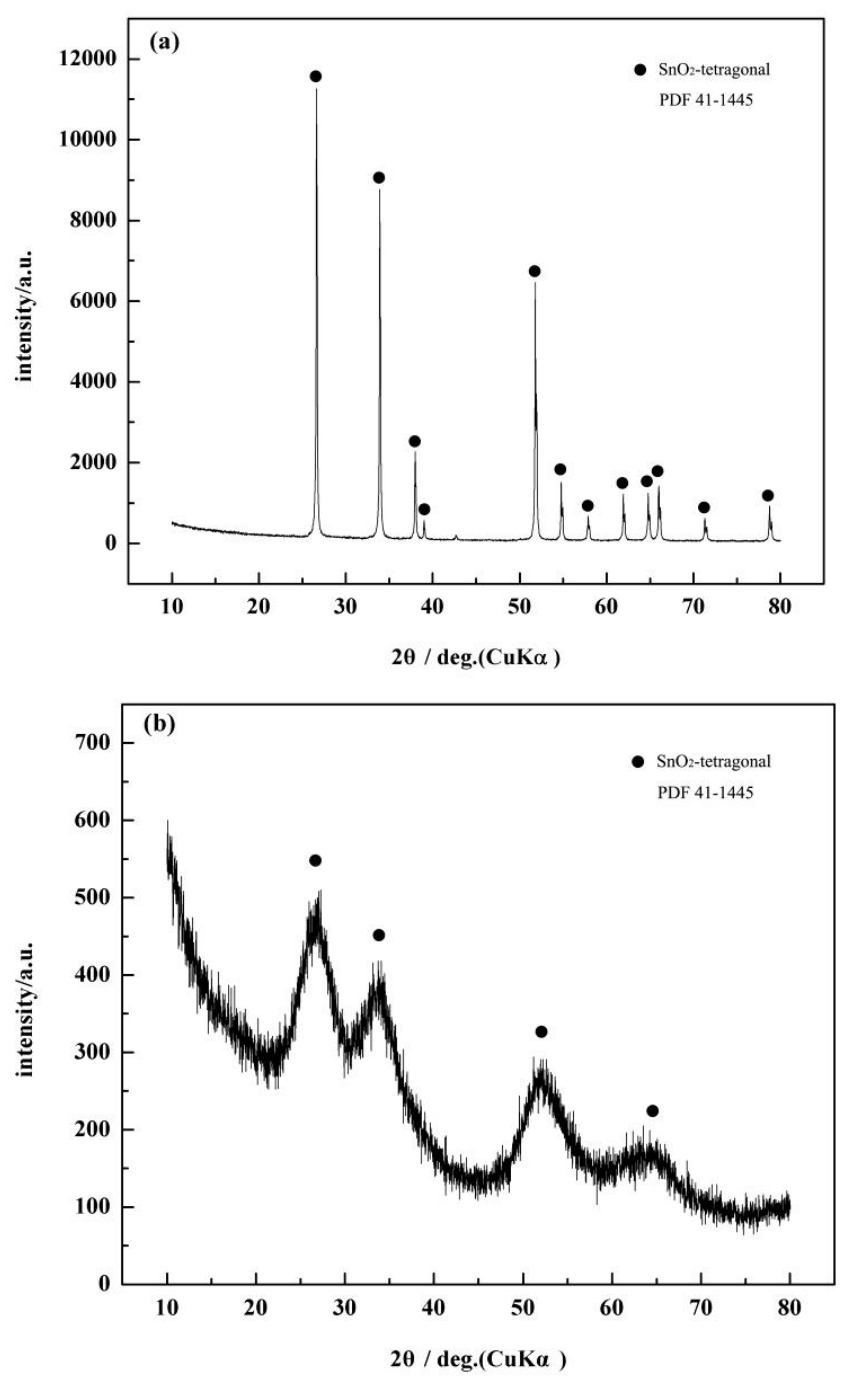

Figure 5. $\mathrm{XRD}$ patterns of the $\mathrm{c}-\mathrm{SnO}_{2}$ powders and the $\mathrm{m}-\mathrm{SnO}_{2}$ powders.: (a) $c-\mathrm{SnO}_{2}$; and (b) $\mathrm{m}-\mathrm{SnO}_{2}$. 


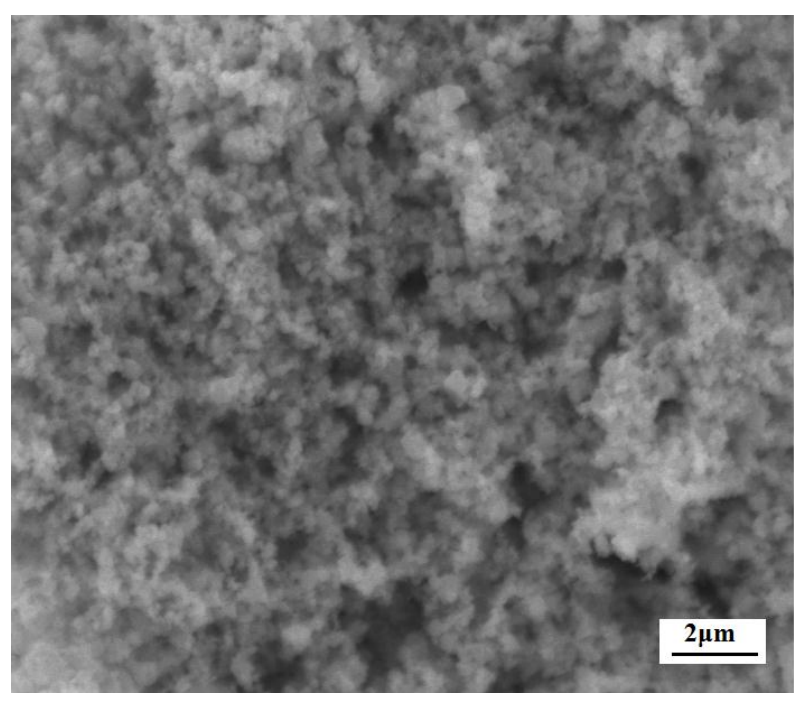

Figure 6. SEM image of the $\mathrm{c}-\mathrm{SnO}_{2}$ powders.

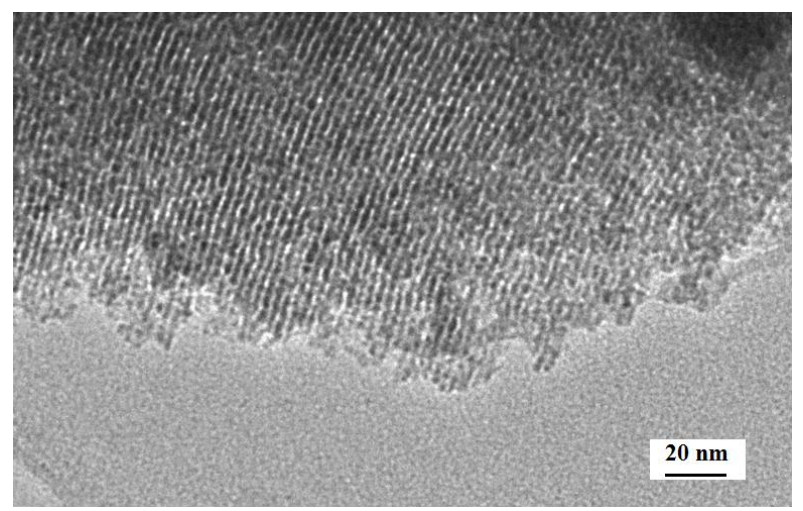

Figure 7. TEM image of the $\mathrm{m}-\mathrm{SnO}_{2}$ powders.

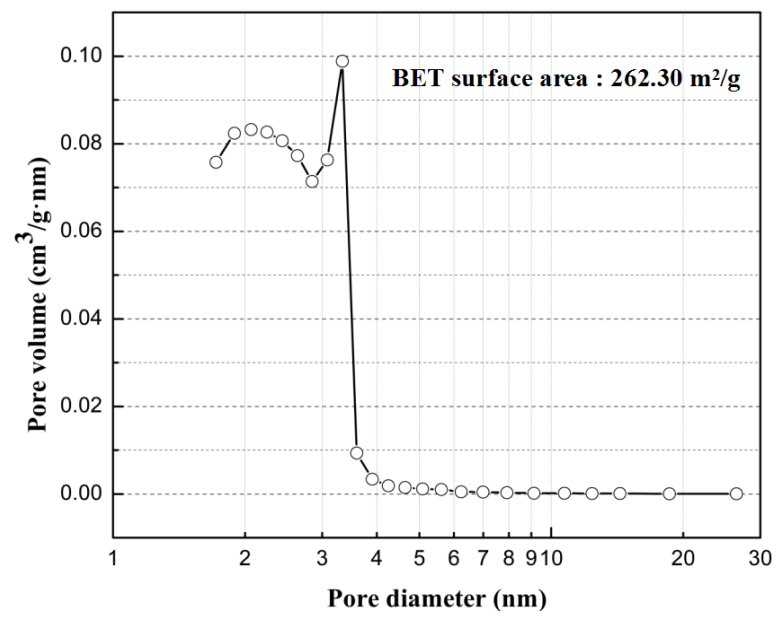

Figure 8. Pore size distribution of the $\mathrm{m}-\mathrm{SnO}_{2}$ powders.

\subsection{Characterization of Gas Sensors}

Figure 9 shows the SEM images of the surface morphology of the gas sensors. It was found that the basic layers of the S(c) sensor were dense and have flat surfaces (see Figure 9a). Moreover, the 
S(c) sensor appeared to have a particle size of approximately dozens of nanometers, despite a small quantity of lager particles. The calcination resulted in some sintered macropores with a size of several hundred nanometers. In contrast, the film of the $S(\mathrm{~m})$ sensor show rough and loosened surfaces, as shown in Figure 9b. It is obvious that the $S(m)$ sensor film showed lager particles (100-200 nm) than that of the $S(c)$ sensor film due to the agglomerations of the particles. The agglomerations of the $\mathrm{m}-\mathrm{SnO}_{2}$ were extremely distinct from those of $\mathrm{c}-\mathrm{SnO}_{2}$. Furthermore, the calcination of the $\mathrm{S}(\mathrm{m})$ sensor resulted in lager sintered macropores. The surface morphology of the other sensors is similar to those of the $S(m)$ sensor (see Figure $9 c-e$ ) because of the same printing materials and printing process.

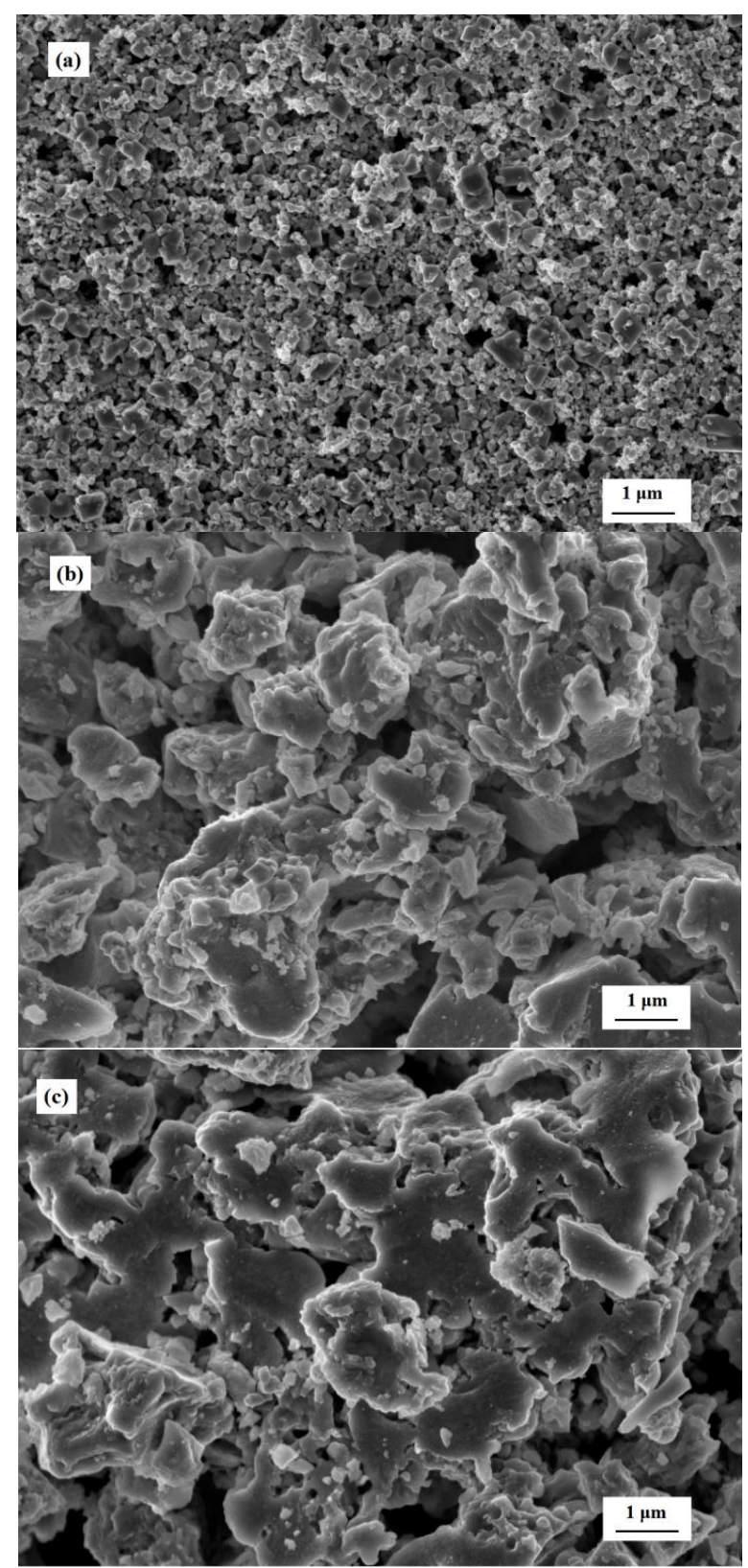

Figure 9. Cont. 


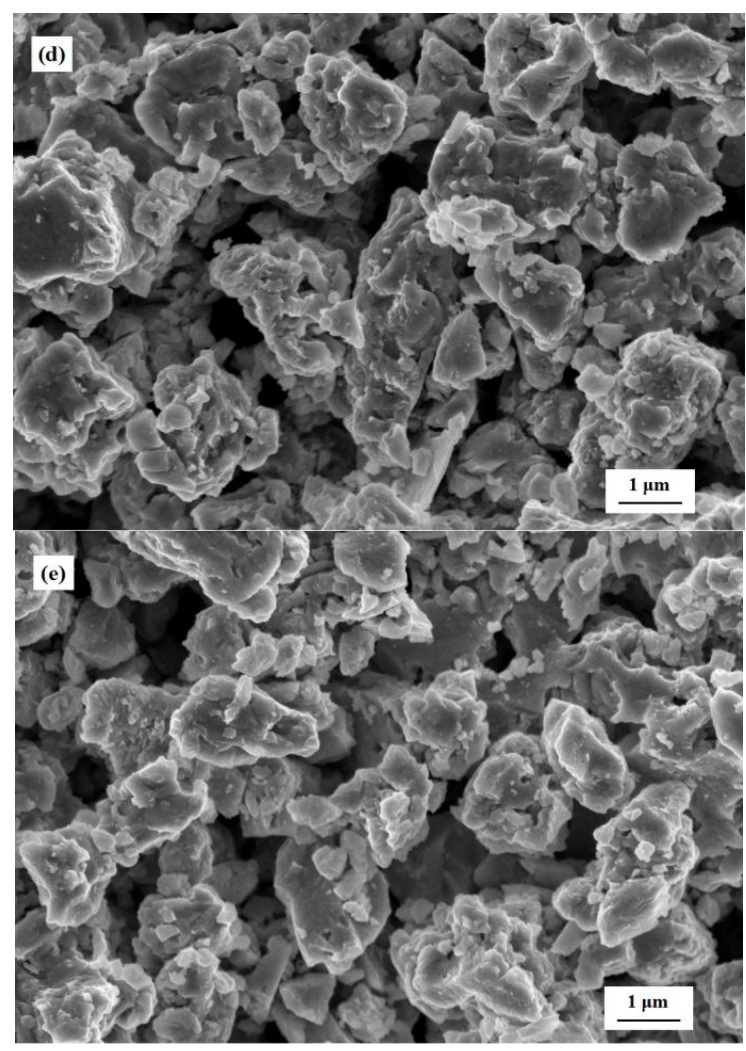

Figure 9. SEM images of the surfaces of the gas sensors: (a) $S(c)$; (b) $S(m)$; (c) $S(c / m 1)$; (d) $S(c / m 2)$; and (e) $\mathrm{S}(\mathrm{c} / \mathrm{m} 3)$.

The SEM images of the cross-sections of the gas sensors are shown in Figure 10. The cross-sectional morphology of the S(c) sensor shows that the calcined c- $\mathrm{SnO}_{2}$ was more compact with the thickness of about $5 \mu \mathrm{m}$ (see Figure 10a), but the modified layers of the $\mathrm{m}-\mathrm{SnO}_{2}$ showed relatively loosened morphology (see Figure 10b). It is apparent that there is an obvious stratification between the $\mathrm{c}-\mathrm{SnO}_{2}$ basic layer and the $\mathrm{m}-\mathrm{SnO}_{2}$ modified layer (see Figure 10c). In addition, fabricated with the same materials and printing manner, the $\mathrm{m}-\mathrm{SnO}_{2}$ modified layers had no stratification to each other. The thickness of each $\mathrm{m}-\mathrm{SnO}_{2}$ modified layer was confirmed with SEM observation to be about $10-15 \mu \mathrm{m}$. Thus, the thickness of the $\mathrm{m}-\mathrm{SnO}_{2}$ modified layers of the $\mathrm{S}(\mathrm{c} / \mathrm{m} 1), \mathrm{S}(\mathrm{c} / \mathrm{m} 2)$ and $\mathrm{S}(\mathrm{c} / \mathrm{m} 3)$ sensors were confirmed to be $15 \mu \mathrm{m}, 31 \mu \mathrm{m}$ and $41 \mu \mathrm{m}$, respectively (see Figure 10c-e).

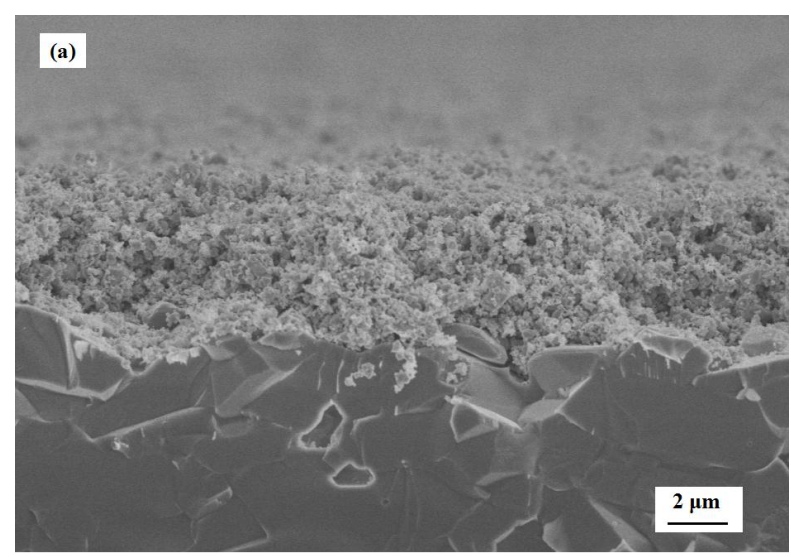

Figure 10. Cont. 

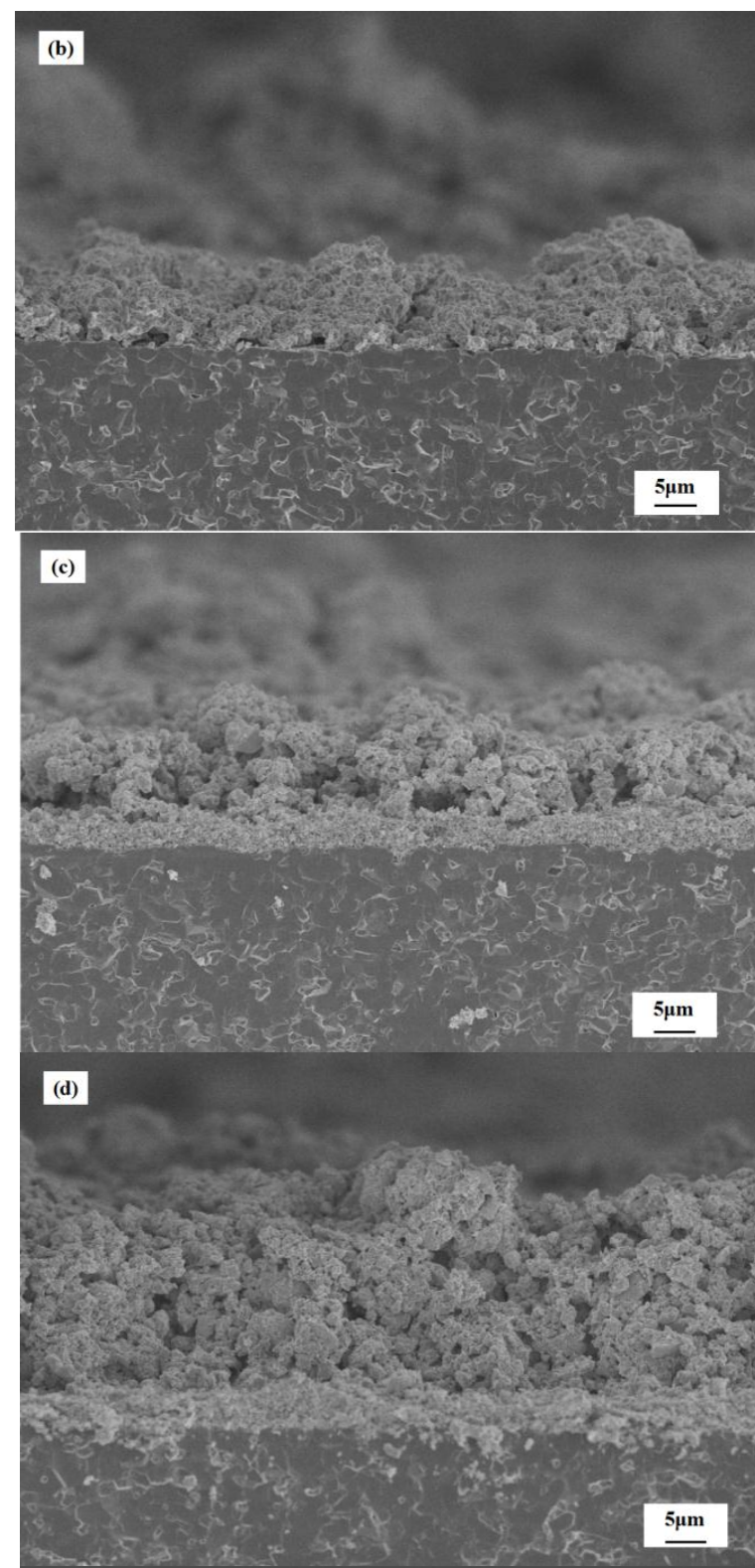

(e)

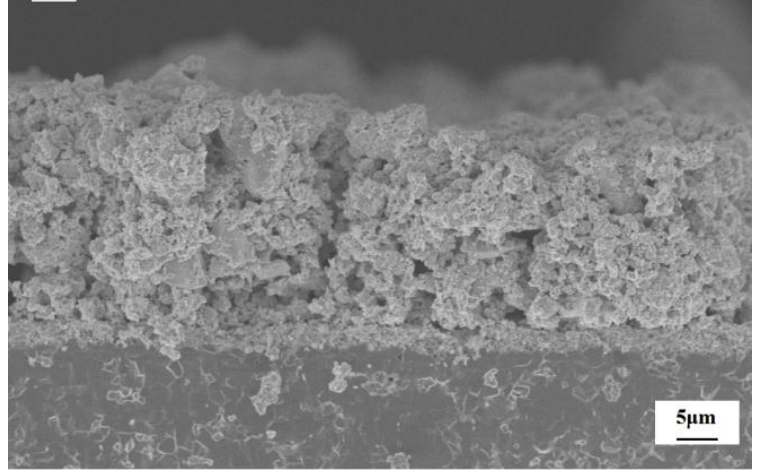

Figure 10. SEM images of the cross-section of the gas sensors: (a) $S(c)$; (b) $S(m)$; (c) $S(c / m 1)$; (d) $S(c / m 2)$; and (e) $S(c / m 3)$. 


\subsection{The Resistance of the Gas Sensors in Air}

Figure 11 shows the temperature dependence of the resistances of the gas sensors in air. As a semiconductor material, the resistance of $\mathrm{SnO}_{2}$ shows decrement trend due to the increase of carriers at the condition of thermal excitation, as confirmed in Figure 11. The higher is the operating temperature in which the gas sensors work, the lower is the resistances in air.

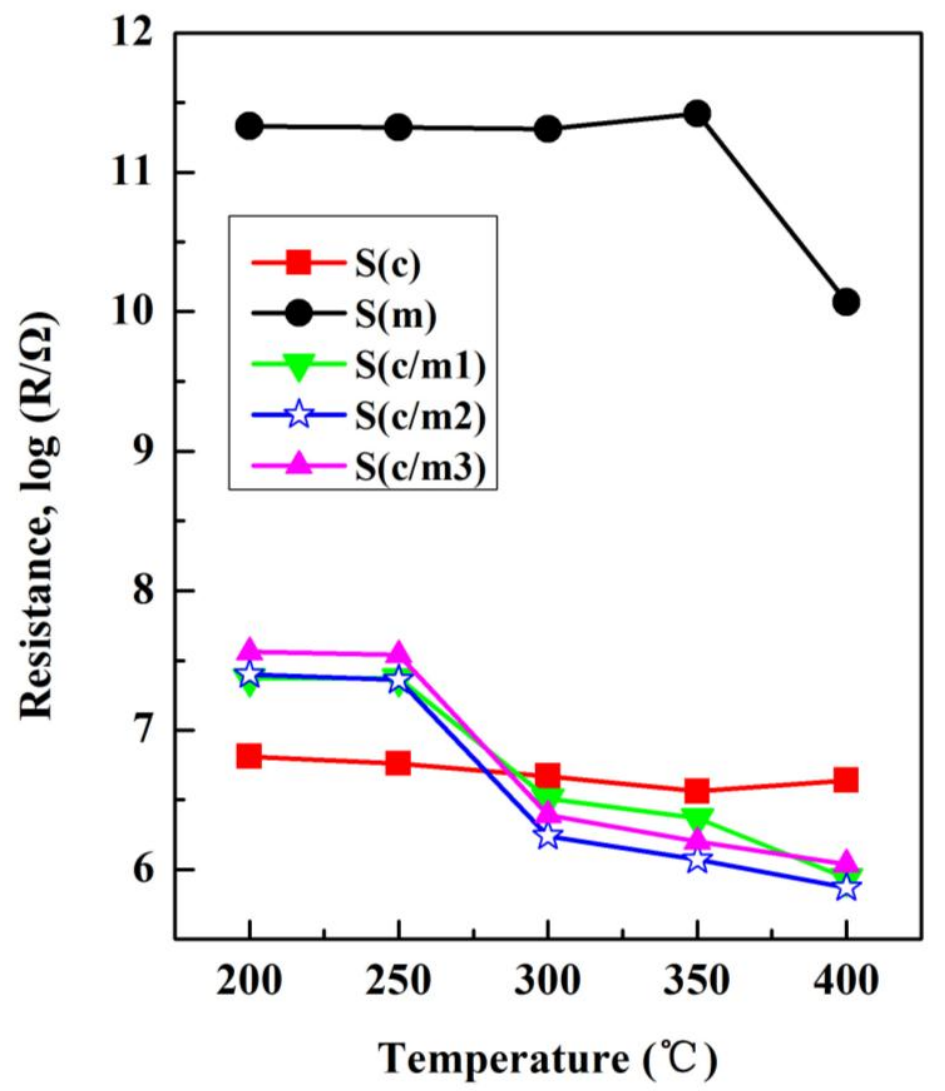

Figure 11. Temperature dependence of the resistances of the gas sensors in air.

The values of the resistance in air of the $S(\mathrm{c})$ sensor were slightly decreased due to the frit. The resistance of the $S(m)$ sensor in air was much higher, which leads to difficult measurement problem in its application. It can be ascribed to the mesoporous structure, which leads to the extreme decrease of conductive path [21]. However, the resistance of the $S(m)$ sensor in air decreased obviously when the operating temperature increased to $400{ }^{\circ} \mathrm{C}$, owing to the condition of thermal excitation [24]. Using the $\mathrm{m}-\mathrm{SnO}_{2}$ as the modified layers, the resistances of the $(\mathrm{S}(\mathrm{c} / \mathrm{m} 1), \mathrm{S}(\mathrm{c} / \mathrm{m} 2)$ and $\mathrm{S}(\mathrm{c} / \mathrm{m} 3))$ sensors changed obviously. Since the resistance of $\mathrm{SnO}_{2}$ semiconductors was affected by thermal excitation, the resistance of the $(\mathrm{S}(\mathrm{c} / \mathrm{m} 1), \mathrm{S}(\mathrm{c} / \mathrm{m} 2)$ and $\mathrm{S}(\mathrm{c} / \mathrm{m} 3))$ sensors in air decreased remarkably when the operating temperature increased to $300^{\circ} \mathrm{C}$. As for the $\mathrm{S}(\mathrm{c} / \mathrm{m} 1), \mathrm{S}(\mathrm{c} / \mathrm{m} 2)$ and $\mathrm{S}(\mathrm{c} / \mathrm{m} 3)$ sensors, the resistance of the $\mathrm{S}(\mathrm{c} / \mathrm{m} 2)$ sensor in air appeared to be the lowest at all the tested operating temperature. The value of the resistance in air of the $\mathrm{S}(\mathrm{c} / \mathrm{m} 2)$ sensor was $3.7 \times 10^{5} \Omega$ at $400{ }^{\circ} \mathrm{C}$. The above results demonstrate that both thermal excitation and adsorption affect the resistance of MOS gas sensors in air. The oxygen adsorbates were considered as the main reason to change the resistance of MOS gas sensors in air. The absorbed $\mathrm{O}_{2}$ on the surface of $\mathrm{SnO}_{2}$ films implies the formation of $\mathrm{O}^{-}$or $\mathrm{O}^{2-}$, which result in a decrease in the quantity of carrier. Thus, the resistance of the sensors fabricated with the modified $\mathrm{m}-\mathrm{SnO}_{2}$ layers in air increased, due to the marked improvement of the adsorption capacity of surface oxygen. However, since the increase of the modified $\mathrm{m}-\mathrm{SnO}_{2}$ layers resulted in larger distance 
for the oxygen adsorbates diffusing to the basic c-SnO $\mathrm{O}_{2}$ layer, as well as the diffusion inhibition of mesoporous to oxygen, the $\mathrm{S}(\mathrm{c} / \mathrm{m} 3)$ sensor showed lower resistance in air than the $\mathrm{S}(\mathrm{c} / \mathrm{m} 2)$ sensor.

\subsection{Sensing Responses to the Testing Gas}

The temperature dependence of the responses to ethanol, benzene and hydrogen are depicted in Figure 12. The response of the $S(\mathrm{c})$ sensor to ethanol at $10 \mathrm{ppm}$ increased slightly with the increasing of operating temperature up to $400{ }^{\circ} \mathrm{C}$, as shown in Figure 12a. However, the responses to ethanol of the $\mathrm{S}(\mathrm{c})$ sensor were lower than those of the $\mathrm{S}(\mathrm{c} / \mathrm{m} 1), \mathrm{S}(\mathrm{c} / \mathrm{m} 2)$ and $\mathrm{S}(\mathrm{c} / \mathrm{m} 3)$ sensors, due to the large specific surface area $\left(262.30 \mathrm{~m}^{2} / \mathrm{g}\right)$ of the $\mathrm{m}-\mathrm{SnO}_{2}$. In addition, the $\mathrm{S}(\mathrm{c} / \mathrm{m} 3)$ sensor showed the largest response $(\mathrm{Ra} / \mathrm{Rg}=11.4)$ to ethanol at $300{ }^{\circ} \mathrm{C}$. The responses to benzene of the $\mathrm{S}(\mathrm{c} / \mathrm{m} 1)$, $\mathrm{S}(\mathrm{c} / \mathrm{m} 2)$ and $\mathrm{S}(\mathrm{c} / \mathrm{m} 3)$ sensors showed a similar tendency: the response decreased at the relatively low operating temperature due to a slight effect of thermal diffusion. While the reaction between testing gas and the basic c-SnO 2 was controlled by gas absorption, the response to benzene was improved with the increasing of operating temperature from $300^{\circ} \mathrm{C}$ to $400{ }^{\circ} \mathrm{C}$ mainly due to the thermal diffusion. The $\mathrm{S}(\mathrm{c} / \mathrm{m} 3)$ sensor exhibited the largest response $(\mathrm{Ra} / \mathrm{Rg}=4.31)$ to benzene at $200^{\circ} \mathrm{C}$, as shown in Figure $12 \mathrm{~b}$. The response to hydrogen increased from $200{ }^{\circ} \mathrm{C}$ to $400{ }^{\circ} \mathrm{C}$ (Figure $12 \mathrm{c}$ ), while the $\mathrm{S}(\mathrm{c} / \mathrm{m} 2$ ) sensor showed the largest response $(\mathrm{Ra} / \mathrm{Rg}=22.2)$ to hydrogen at $400{ }^{\circ} \mathrm{C}$. It can be deduced from the hydrogen molecular diffusion that the small molecular dimension of hydrogen benefits the gas diffusion. While gas adsorbing capacity was enhanced, the response to hydrogen was highly improved (see Figure 12c). All of the above results confirmed that the modified layers of the $\mathrm{m}-\mathrm{SnO}_{2}$ contribute to improving the response of the S(c) sensor sufficiently. Moreover, the magnitude of the response enhancement is not directly proportional to the amount of the $\mathrm{m}-\mathrm{SnO}_{2}$.

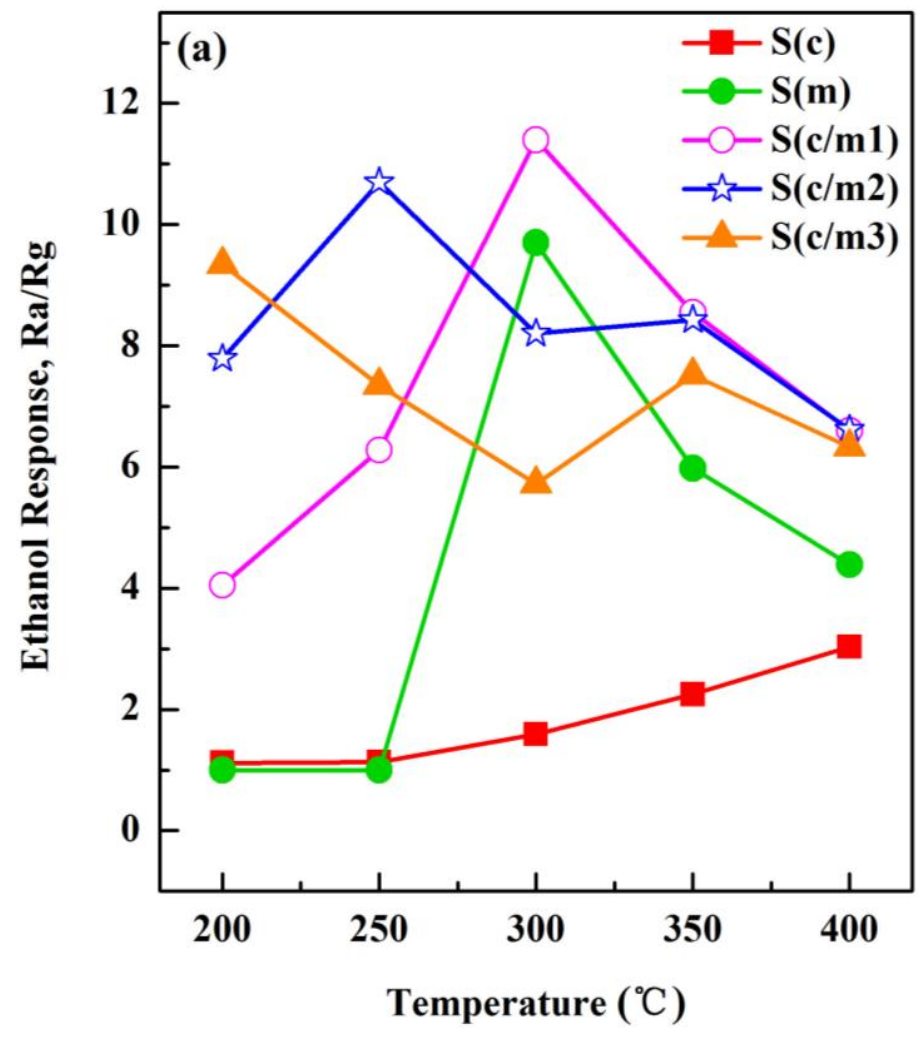

Figure 12. Cont. 

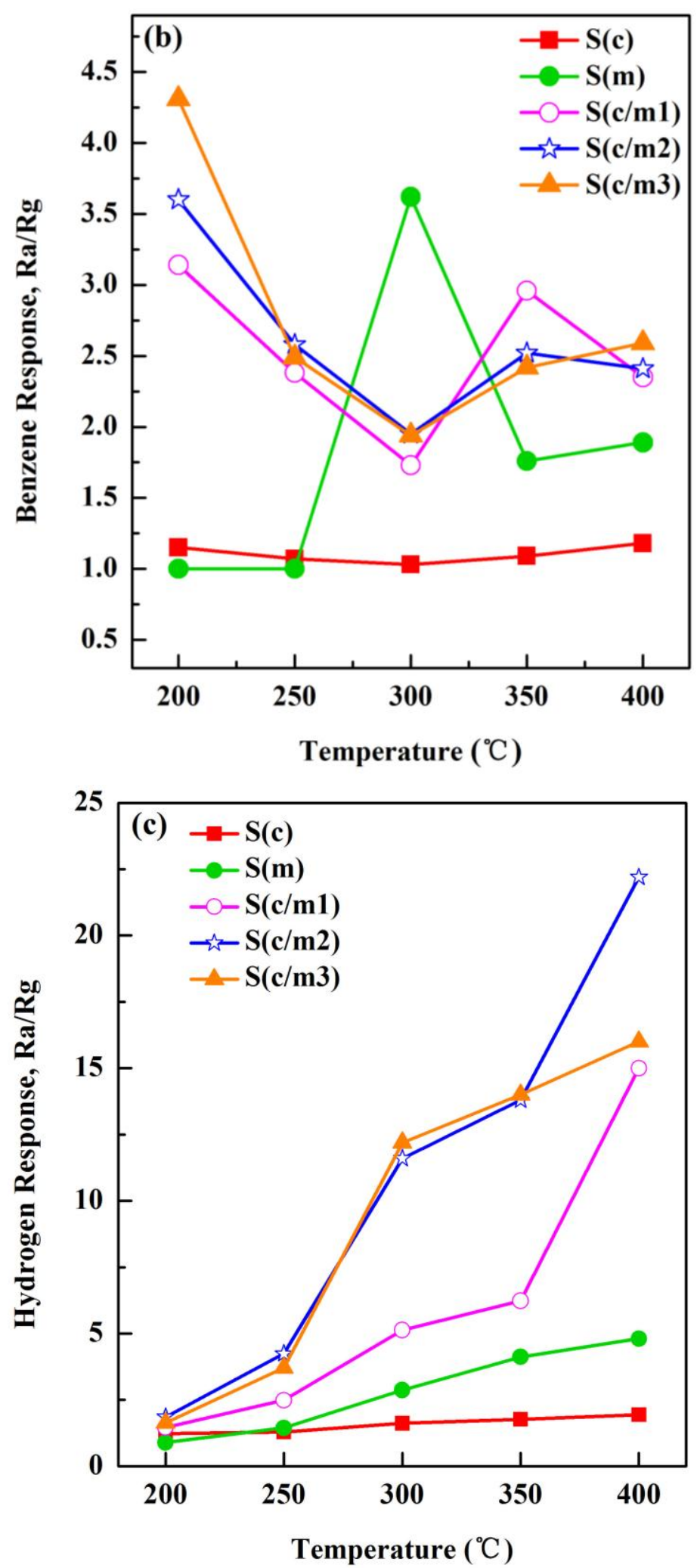

Figure 12. Temperature dependence of the responses of the gas sensors: (a) ethanol at 10 ppm; (b) benzene at $10 \mathrm{ppm}$; and (c) hydrogen at $1000 \mathrm{ppm}$.

To further investigate the effects of the modified $\mathrm{m}-\mathrm{SnO}_{2}$ layers, the evolutions of the response versus thickness of the modified films of the gas sensors at $400{ }^{\circ} \mathrm{C}$ are depicted in Figure 13. It is clear 
that the response of the $\mathrm{S}(\mathrm{c} / \mathrm{m} 1), \mathrm{S}(\mathrm{c} / \mathrm{m} 2)$ and $\mathrm{S}(\mathrm{c} / \mathrm{m} 3)$ sensors to ethanol, benzene and hydrogen were all improved to a certain extent in comparison to the $S$ (c) sensor response, which means higher gas sensitivities. Especially, the response of the $\mathrm{S}(\mathrm{c} / \mathrm{m} 2)$ sensor to hydrogen appeared to improve by 11.4 times, compared to benzene and ethanol improvements of 2.03 and 2.18 times, respectively.

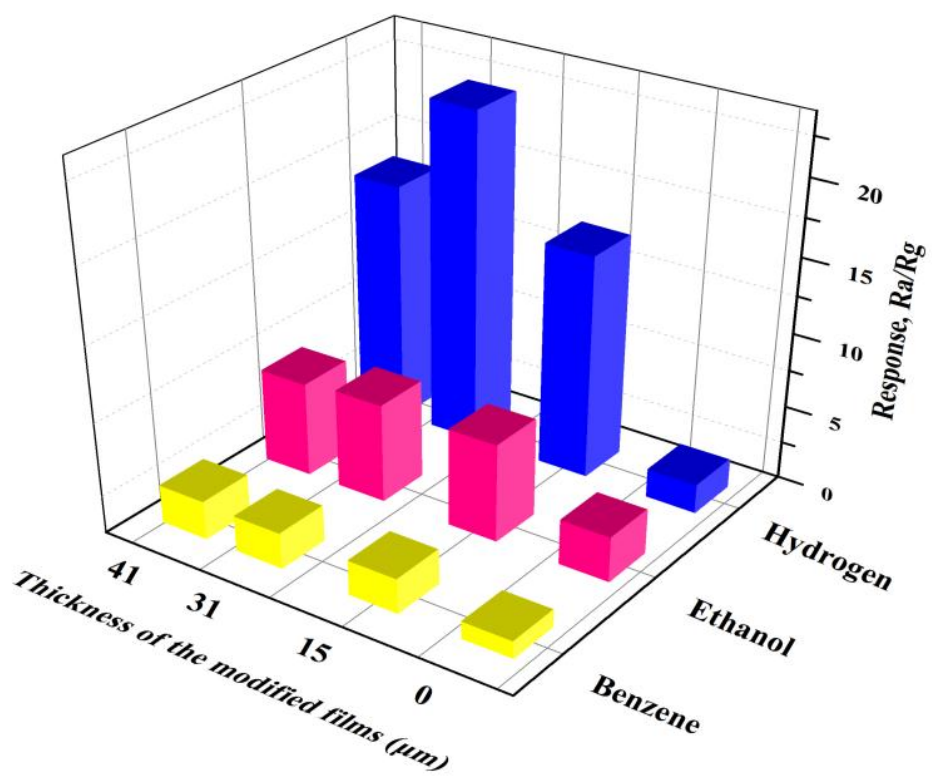

Figure 13. Evolutions of the response versus thickness of the modified films of the gas sensors at $400{ }^{\circ} \mathrm{C}$. The thickness of the modified films with the gas sensors: $S(c), 0 \mu \mathrm{m} ; \mathrm{S}(\mathrm{c} / \mathrm{m} 1), 15 \mu \mathrm{m} ; \mathrm{S}(\mathrm{c} / \mathrm{m} 2), 31 \mu \mathrm{m}$; and $S(\mathrm{c} / \mathrm{m} 3), 41 \mu \mathrm{m}$.

\subsection{The Response and Recovery Times of the Gas Sensors}

Table 2 shows the response and recovery times of the gas sensors to ethanol, benzene and hydrogen. The response and recovery times of some of the gas sensors were difficult to summarize due to the lower response at low operating temperature. The response time of the $\mathrm{S}$ (c) sensor to ethanol was markedly short from $350{ }^{\circ} \mathrm{C}$ (response time $=115 \mathrm{~s}$ ) to $400{ }^{\circ} \mathrm{C}$ (response time $=54 \mathrm{~s}$ ), while the values of response time to hydrogen at $350{ }^{\circ} \mathrm{C}$ and $400^{\circ} \mathrm{C}$ were $80 \mathrm{~s}$ and $89 \mathrm{~s}$, respectively. However, the response times of benzene were hard to summarize because of the relatively large molecular dimension $(0.65-0.68 \mathrm{~nm})$, which led to the low response to benzene. In the case of the $\mathrm{S}(\mathrm{c} / \mathrm{m} 1), \mathrm{S}(\mathrm{c} / \mathrm{m} 2)$ and $\mathrm{S}(\mathrm{c} / \mathrm{m} 3)$ sensors, the response times increased with the thicker modified $\mathrm{m}-\mathrm{SnO}_{2}$ layers for all of the tested gases at $350{ }^{\circ} \mathrm{C}$ and $400{ }^{\circ} \mathrm{C}$. In addition, the smallest response time appeared to be $74 \mathrm{~s}$ with the $\mathrm{S}(\mathrm{c} / \mathrm{m} 1)$ sensors to hydrogen at $400{ }^{\circ} \mathrm{C}$. It can be ascribed to the large specific surface area and the molecular diffusion at high temperature, both of which lead to easy gas diffusion inside the mesopores.

All gas sensors showed longer recovery times to ethanol and benzene in comparison to hydrogen from $350^{\circ} \mathrm{C}$ to $400{ }^{\circ} \mathrm{C}$. Especially, the $\mathrm{S}(\mathrm{c} / \mathrm{m} 1), \mathrm{S}(\mathrm{c} / \mathrm{m} 2)$ and $\mathrm{S}(\mathrm{c} / \mathrm{m} 3)$ sensors tended to show a longer response time $(>500 \mathrm{~s})$ to hydrogen than to ethanol $(<467 \mathrm{~s})$ and benzene $(<207 \mathrm{~s})$. 
Table 2. The response and recovery times of the gas sensors to ethanol, benzene and hydrogen.

\begin{tabular}{|c|c|c|c|c|c|c|c|c|c|c|c|}
\hline \multirow{2}{*}{ Gas } & \multirow{2}{*}{ Temperature $\left({ }^{\circ} \mathrm{C}\right)$} & \multicolumn{5}{|c|}{ Response Time (s) } & \multicolumn{5}{|c|}{ Recovery Time (s) } \\
\hline & & $S(c)$ & $\mathrm{S}(\mathrm{m})$ & $\mathrm{S}(\mathrm{c} / \mathrm{m} 1)$ & $\mathrm{S}(\mathrm{c} / \mathrm{m} 2)$ & $\mathrm{S}(\mathrm{c} / \mathrm{m} 3)$ & $S(c)$ & $S(m)$ & $\mathrm{S}(\mathrm{c} / \mathrm{m} 1)$ & $\mathrm{S}(\mathrm{c} / \mathrm{m} 2)$ & $\mathrm{S}(\mathrm{c} / \mathrm{m} 3)$ \\
\hline \multirow{5}{*}{ Ethanol } & 200 & - & - & 286 & 496 & 549 & - & - & 292 & 519 & $>600$ \\
\hline & 250 & - & - & 252 & 277 & 180 & - & - & 281 & 355 & 349 \\
\hline & 300 & 126 & 19 & 197 & 106 & 87 & 14 & 90 & 178 & 182 & 142 \\
\hline & 350 & 115 & 41 & 127 & 289 & 430 & 26 & 271 & 246 & 235 & 226 \\
\hline & 400 & 54 & 56 & 152 & 210 & 295 & 37 & 201 & 467 & 467 & 462 \\
\hline \multirow{5}{*}{ Benzene } & 200 & - & - & $>600$ & $>600$ & $>600$ & - & - & $>600$ & $>600$ & $>600$ \\
\hline & 250 & - & - & 360 & 486 & $>600$ & - & - & 60 & 158 & $>600$ \\
\hline & 300 & - & - & 110 & 225 & 403 & - & - & 14 & 12 & 13 \\
\hline & 350 & - & - & 411 & 422 & 478 & - & - & 89 & 63 & 78 \\
\hline & 400 & - & - & 173 & 218 & 293 & - & - & 207 & 103 & 115 \\
\hline \multirow{5}{*}{ Hydrogen } & 200 & - & - & 344 & 343 & 349 & - & - & 84 & 216 & 233 \\
\hline & 250 & - & - & 261 & 162 & 146 & - & - & 387 & 406 & 404 \\
\hline & 300 & 83 & 131 & 96 & 82 & 87 & 194 & $>600$ & 423 & 451 & 442 \\
\hline & 350 & 80 & 144 & 87 & 110 & 121 & 165 & $>600$ & 568 & $>600$ & $>600$ \\
\hline & 400 & 89 & 34 & 74 & 105 & 110 & 139 & $>600$ & 507 & 519 & 520 \\
\hline
\end{tabular}

\subsection{Discussion}

Among these, the possible gas sensing mechanism of the gas sensors are shown in Figure 14. It is considered that the adsorption/desorption properties of the mesoporous influenced the gas sensing performances of the gas sensors. Owing to the large specific surface area of $\mathrm{m}-\mathrm{SnO}_{2}$, which could enhance the adsorption of gas molecules, the $S(\mathrm{c} / \mathrm{m} 1) \mathrm{S}(\mathrm{c} / \mathrm{m} 2)$ and $\mathrm{S}(\mathrm{c} / \mathrm{m} 3)$ sensors exhibited higher gas (ethanol, benzene, and hydrogen) responses than those of the $\mathrm{S}$ (c) sensor. The responses of benzene are lower than those of ethanol and hydrogen because of its weak reducibility and larger size of benzene ring, which is difficult to pass through the $\mathrm{m}-\mathrm{SnO}_{2}$ modified layer. However, the sintered macropores (Figure 14) among the $\mathrm{m}-\mathrm{SnO}_{2}$ is helpful to adsorb more benzene molecules. This is why the responses of the $\mathrm{S}(\mathrm{c} / \mathrm{m} 1), \mathrm{S}(\mathrm{c} / \mathrm{m} 2)$ and $\mathrm{S}(\mathrm{c} / \mathrm{m} 3)$ sensors to benzene are higher than those of the $\mathrm{S}(\mathrm{c})$ sensor to benzene. In contrast, the smaller molecular size of the hydrogen is beneficial to pass through the ordered structure of $\mathrm{m}-\mathrm{SnO}_{2}$ and the sintered macropores. Thus, thickness of the films and the ordered level of mesoporous influenced the gas sensing performance of the gas sensors fabricated with the modified $\mathrm{m}-\mathrm{SnO}_{2}$ layers. In addition, further approaches to control the amount of sintered macropores, the thickness of the films, surface contact of the films and the ordered level of mesoporous would be effective to improve the sensing performance of the gas sensors.

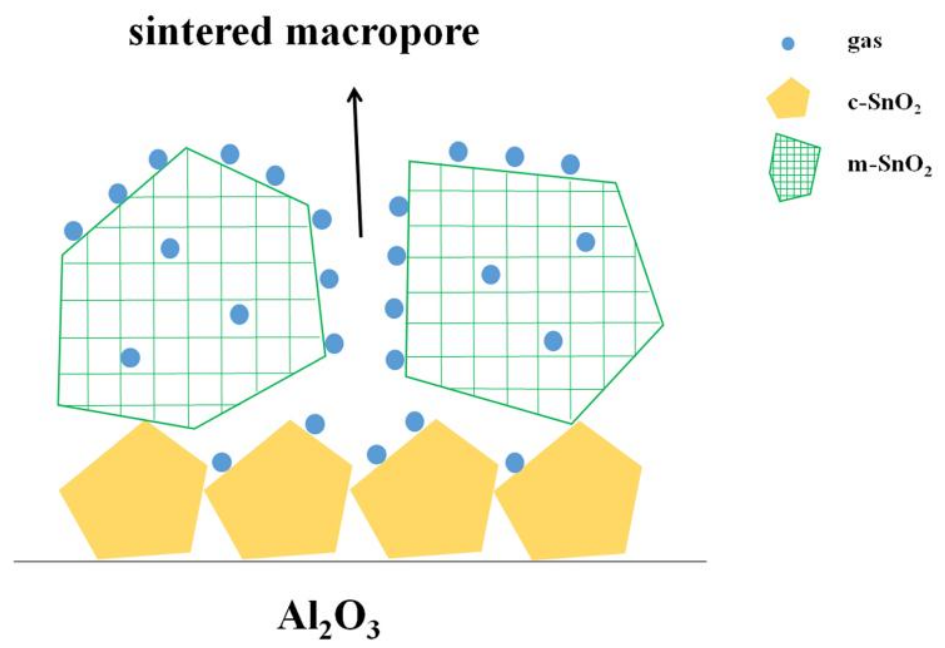

Figure 14. Schematic drawing of the possible gas sensing mechanism of the gas sensors.

Experimental results of $\mathrm{SnO}_{2}$ sensors have been compared with the results reported by the other researchers on $\mathrm{H}_{2}$ sensors. Manjula et al. reported the $\mathrm{Pd}$ doped $\mathrm{m}-\mathrm{SnO}_{2}$ gas sensors. It showed 
that the $0.25 \% \mathrm{Pd}$ doped gas sensor response towards $1000 \mathrm{ppm}$ hydrogen at $50{ }^{\circ} \mathrm{C}$ is 0.95 . The gas sensors showed zero response to ethanol, LPG, $\mathrm{NH}_{3}$ and acetone [25]. Seftel et al. obtained gas sensing material by combining Pt with $\mathrm{SnO}_{2}$ or $\mathrm{In}_{2} \mathrm{O}_{3}$ based on SBA-15. The response of the gas sensor based on $\mathrm{Pt} / \mathrm{SnO}_{2} / \mathrm{SBA}-15$ is about 1.4 to $1000 \mathrm{ppm}$ hydrogen at $350{ }^{\circ} \mathrm{C}$ [26]. Although the selectivity of the sensors was improved by doping, the responses of the sensors to hydrogen are no more than 2 , which limits the applications of the sensors in hydrogen measurement.

We can find a large number of examples of sensitivities improvement of gas sensors to hydrogen when mesoporous structures are employed. Shen et al. reported that the influence of the different morphology of $\mathrm{SnO}_{2}$ nanomaterials on hydrogen sensing properties. They obtained the response of about 2.1 to $1000 \mathrm{ppm}$ hydrogen at $250^{\circ} \mathrm{C}$ for nanofilms [27]. Yeow et al. reported the gas sensors based on $\mathrm{SnO}_{2}$ nanospheres with various degrees porosity. The reference $\left(\mathrm{SSA}_{\mathrm{SnO}_{2}}=101.4 \mathrm{~m}^{2} / \mathrm{g}\right.$ ) gas sensor showed the largest response: 5.2 to $500 \mathrm{ppm}$ hydrogen at $350{ }^{\circ} \mathrm{C}$ [28]. Zhao et al. prepared ordered mesoporous $\mathrm{SnO}_{2}$ and mesoporous $\mathrm{Pd} / \mathrm{SnO}_{2}$ via nanocasting method using the hexagonal mesoporous SBA-15 as template. The maximum response of the sensor based on the ordered mesoporous $\mathrm{SnO}_{2}$ is 16.4 to $1000 \mathrm{ppm}$ hydrogen at $300{ }^{\circ} \mathrm{C}$ [29]. Hayashi et al. prepared $\mathrm{SnO}_{2}$ gas sensors based on various $\mathrm{m}-\mathrm{SnO}_{2}$ powders from two kinds of combination of tin source and surfactant template. The largest response of the gas sensors to $1000 \mathrm{ppm}$ hydrogen at $350{ }^{\circ} \mathrm{C}$ appeared to be 42 [30]. It is evidential that the responses of the sensors based on the ordered mesoporous $\mathrm{SnO}_{2}$ to hydrogen have been dramatically increased. The one limitation of these studies is that the selectivity of the mesoporous $\mathrm{SnO}_{2}$ has not been studied.

Shahabuddin et al. reported the sputter deposited $\mathrm{SnO}_{2}$ thin film gas sensors with $9 \mathrm{~nm}$ thin Pt clusters. The $\mathrm{Pt} / \mathrm{SnO}_{2}$ sensor shows an improvement in sensing response: 168 towards $500 \mathrm{ppm}$ of hydrogen at $110{ }^{\circ} \mathrm{C}$. The sensor revealed negligible cross sensing signals against acetone, IPA, $\mathrm{NO}_{2}$, methane, LPG, etc. [10]. Gong et al. reported the mesoporous nanocrystalline $\mathrm{SnO}_{2}$ gas sensor based on the fabricated $\mathrm{SnO}_{2}$ sputtering with $\mathrm{Pt}$ thin film. The gas sensor showed the response of about 1.8 to $1000 \mathrm{ppm}$ hydrogen at $250^{\circ} \mathrm{C}$ [31]. The sensitivities and selectivity of the $\mathrm{SnO}_{2}$ gas sensors could be significantly improved by sputtering with $\mathrm{Pt}$ thin film. However, the method requires an expensive facility and complex sample preparing process.

In our work, the ordered mesoporous $\mathrm{SnO}_{2}$ was prepared by simple sol-gel method. The gas sensors were prepared with a simple and low cost screen printing method while the mesoporous $\mathrm{SnO}_{2}$ worked as the modified layers. It was shown that both the sensitivities and the selectivity of the gas sensors to hydrogen were improved. The $S(\mathrm{c} / \mathrm{m} 2)$ sensor showed the largest response 22.2 to $1000 \mathrm{ppm}$ hydrogen at $400{ }^{\circ} \mathrm{C}$. The response to hydrogen is $>10$ times higher than that of the sensor without the modified layer (the S(c) sensor). Compared with the responses of the $S(c)$ sensor, the responses of the $\mathrm{S}(\mathrm{c} / \mathrm{m} 2)$ sensor to benzene and ethanol did not change significantly.

\section{Conclusions}

Ordered mesoporous $\mathrm{SnO}_{2}$ powders were prepared by employing $\mathrm{Na}_{2} \mathrm{SnO}_{3} \cdot 4 \mathrm{H}_{2} \mathrm{O}, \mathrm{C}_{16} \mathrm{PyCl}$ and trimethylbenzene. The specific surface area of the $\mathrm{m}-\mathrm{SnO}_{2}$ powder was $262.30 \mathrm{~m}^{2} / \mathrm{g}$ after calcination at $600{ }^{\circ} \mathrm{C}$. The gas sensors were fabricated using $\mathrm{m}-\mathrm{SnO}_{2}$ films as the modified layers. It was proven that the gassensing performance of the gas sensors could be highly improved, especially to hydrogen, compared with ethanol or benzene gas. In addition, the $\mathrm{S}(\mathrm{c} / \mathrm{m} 2)$ sensor exhibited the highest sensitivity (response: $\mathrm{Ra} / \mathrm{Rg}=22.2$ ) to $1000 \mathrm{ppm}$ hydrogen at $400{ }^{\circ} \mathrm{C}$. The main reason for the high selectivity may be the diffusivity of hydrogen molecules in the ordered mesopores is easier than that of ethanol and benzene molecules.

Acknowledgments: This work was founded by the Scientific Research Foundation for Returned Scholars, Ministry of Education of China, and the National Science Foundation of China (Grant No. 51502229).

Author Contributions: Qinyi Zhang and Niuzi Xue conceived and designed the experiments; Niuzi Xue, Feng Yang and Pan Zong performed the experiments; Niuzi Xue and Qinyi Zhang analyzed the data; Shunping Zhang contributed the test tools; and Niuzi Xue wrote the paper. 
Conflicts of Interest: The authors declare no conflict of interest.

\section{References}

1. Cao, S.; Klein, K.; Herkel, S.; Sirén, K. Approaches to enhance the energy performance of a zero-energy building integrated with a commercial-scale hydrogen fueled zero-energy vehicle under finnish and german conditions. Energy Convers. Manag. 2017, 142, 153-175. [CrossRef]

2. Andronov, D.Y.; Arseniev, D.G.; Polyanskiy, A.M.; Polyanskiy, V.A.; Yakovlev, Y.A. Application of multichannel diffusion model to analysis of hydrogen measurements in solid. Int. J. Hydrogen Energy 2017, 42, 699-710. [CrossRef]

3. Bockris, J.O.M. On hydrogen futures: Toward a sustainable energy system. Int. J. Hydrogen Energy 2003, 28, 131-133. [CrossRef]

4. Cardozacontrera, M.N.; Romoherrera, J.M.; Ríos, L.A.; Garcíagutiérrez, R.; Zepeda, T.A.; Contreras, O.E. Single ZnO Nanowire-Based Gas Sensors to Detect Low Concentrations of Hydrogen. Sensors 2015, 15, 30539-30544. [CrossRef] [PubMed]

5. Kim, S.; Choi, J.; Jung, M.; Joo, S.; Kim, S. Silicon carbide-based hydrogen gas sensors for high-temperature application. Sensors 2013, 13, 13575-13583. [CrossRef] [PubMed]

6. Kim, H.W.; Kwon, Y.J.; Mirzaei, A.; Kang, S.Y.; Choi, M.S.; Bang, J.H.; Kim, S.S. Synthesis of zinc oxide semiconductors-graphene nanocomposites by microwave irradiation for application to gas sensors. Sens. Actuators B Chem. 2017, 249, 590-601. [CrossRef]

7. Wongchoosuk, C.; Wisitsoraat, A.; Phokharatkul, D.; Tuantranont, A.; Kerdcharoen, T. Multi-Walled Carbon Nanotube-Doped Tungsten Oxide Thin Films for Hydrogen Gas Sensing. Sensors 2010, 10, 7705-7715. [CrossRef] [PubMed]

8. Krško, O.; Plecenik, T.; Roch, T.; Grančič, B.; Satrapinskyy, L.; Truchlý, M.; Ďurina, P.; Gregor, M.; Kúš, P.; Plecenik, A. Flexible highly sensitive hydrogen gas sensor based on a $\mathrm{TiO}_{2}$ thin film on polyimide foil. Sens. Actuators B Chem. 2017, 240, 1058-1065. [CrossRef]

9. Kimura, Y.; Kimura, S.; Kojima, R.; Bitoh, M.; Abe, M.; Niwano, M. Micro-scaled hydrogen gas sensors with patterned anodic titanium oxide nanotube film. Sens. Actuators B Chem. 2013, 177, 1156-1160. [CrossRef]

10. Shahabuddin, M.; Umar, A.; Tomar, M.; Gupta, V. Custom designed metal anchored $\mathrm{SnO}_{2}$ sensor for $\mathrm{H}_{2}$ detection. Int. J. Hydrogen Energy 2017, 42, 4597-4609. [CrossRef]

11. Nguyen, V.T.; Nguyen, V.C.; Nguyen, V.D.; Hoang, S.H.; Hugo, N.; Nguyen, D.H.; Nguyen, V.H. Fabrication of highly sensitive and selective $\mathrm{H}_{2}$ gas sensor based on $\mathrm{SnO}_{2}$ thin film sensitized with microsized Pd islands. J. Hazard. Mater. 2016, 301, 433-442. [PubMed]

12. Ammar, A.H.; Abo-Ghazala, M.S.; Farag, A.A.M.; Abdel-Moniem, N.M.; Farag, E.-S.M. Effect of gas type, pressure and temperature on the electrical characteristics of Al-doped $\mathrm{SnO}_{2}$ thin films deposited by RGTO method for gas sensor application. Vacuum 2013, 94, 30-40. [CrossRef]

13. Inyawilert, K.; Wisitsoraat, A.; Tuantranont, A.; Phanichphant, S.; Liewhiran, C. Ultra-sensitive and highly selective $\mathrm{H}_{2}$ sensors based on FSP-made Rh-substituted $\mathrm{SnO}_{2}$ sensing films. Sens. Actuators B Chem. 2017, 240, 1141-1152. [CrossRef]

14. Bianchetti, M.F.; Arrieta, C.; Walsöe de Reca, N.E. Microstructural study of nanocrystalline pure and doped tin dioxide to be used for resistive gas sensors. Sens. Actuators B Chem. 2015, 217, 113-118. [CrossRef]

15. Liewhiran, C.; Tamaekong, N.; Wisitsoraat, A.; Tuantranont, A.; Phanichphant, S. Ultra-sensitive $\mathrm{H}_{2}$ sensors based on flame-spray-made Pd-loaded $\mathrm{SnO}_{2}$ sensing films. Sens. Actuators B Chem. 2013, 176, 893-905. [CrossRef]

16. Jang, B.-H.; Landau, O.; Choi, S.-J.; Shin, J.; Rothschild, A.; Kim, I.-D. Selectivity enhancement of $\mathrm{SnO}_{2}$ nanofiber gas sensors by functionalization with $\mathrm{Pt}$ nanocatalysts and manipulation of the operation temperature. Sens. Actuators B Chem. 2013, 188, 156-168. [CrossRef]

17. Yamaguchi, M.; Anggraini, S.A.; Fujio, Y.; Sato, T.; Breedon, M.; Miura, N. Stabilized zirconia-based sensor utilizing $\mathrm{SnO}_{2}$-based sensing electrode with an integrated $\mathrm{Cr}_{2} \mathrm{O}_{3}$ catalyst layer for sensitive and selective detection of hydrogen. Int. J. Hydrogen Energy 2013, 38, 305-312. [CrossRef]

18. Tournier, G.; Pijolat, C. Selective filter for SnO-based gas sensor: Application to hydrogen trace detection. Sens. Actuators B Chem. 2005, 106, 553-562. [CrossRef] 
19. Masuzawa, S.; Okazaki, S.; Maru, Y.; Mizutani, T. Catalyst-type-an optical fiber sensor for hydrogen leakage based on fiber bragg gratings. Sens. Actuators B Chem. 2015, 217, 151-157. [CrossRef]

20. Yaqoob, U.; Uddin, A.S.M.I.; Chung, G.-S. Foldable hydrogen sensor using Pd nanocubes dispersed into multiwall carbon nanotubes-reduced graphene oxide network assembled on nylon filter membrane. Sens. Actuators B Chem. 2016, 229, 355-361. [CrossRef]

21. Hyodo, T.; Abe, S.; Shimizu, Y.; Egashira, M. Gas-sensing properties of ordered mesoporous $\mathrm{SnO}_{2}$ and effects of coatings thereof. Sens. Actuators B Chem. 2003, 93, 590-600. [CrossRef]

22. Pijolat, C.; Viricelle, J.P.; Tournier, G.; Montmeat, P. Application of membranes and filtering films for gas sensors improvements. Thin Solid Films 2005, 490, 7-16. [CrossRef]

23. Dhawale, D.S.; Lokhande, C.D. Chemical route to synthesis of mesoporous ZnO thin films and their liquefied petroleum gas sensor performance. J. Alloys Compd. 2011, 509, 10092-10097. [CrossRef]

24. Das, S.; Jayaraman, V. $\mathrm{SnO}_{2}$ : A comprehensive review on structures and gas sensors. Prog. Mater. Sci. 2014, 66, 112-255. [CrossRef]

25. Manjula, P.; Satyanarayana, L.; Swarnalatha, Y.; Manorama, S.V. Raman and MASNMR studies to support the mechanism of low temperature hydrogen sensing by $\mathrm{Pd}$ doped mesoporous $\mathrm{SnO}_{2}$. Sens. Actuators B Chem. 2009, 138, 28-34. [CrossRef]

26. Seftel, E.M.; Cool, P.; Lloyd-Spetz, A.; Lutic, D. Pt-doped semiconductive oxides loaded on mesoporous SBA-15 for gas sensing. Comptes Rendus Chim. 2014, 17, 717-724. [CrossRef]

27. Shen, Y.; Wang, W.; Fan, A.; Wei, D.; Liu, W.; Han, C.; Shen, Y.; Meng, D.; San, X. SnO 2 : Highly sensitive hydrogen sensors based on $\mathrm{SnO}_{2}$ nanomaterials with different morphologies. Int. J. Hydrogen Energy 2015, 40, 15773-15779. [CrossRef]

28. Yeow, S.C.; Ong, W.L.; Wong, A.S.W.; Ho, G.W. Template-free synthesis and gas sensing properties of well-controlled porous tin oxide nanospheres. Sens. Actuators B Chem. 2009, 143, 295-301. [CrossRef]

29. Zhao, J.; Wang, W.; Liu, Y.; Ma, J.; Li, X.; Du, Y.; Lu, G. Ordered mesoporous Pd/SnO 2 synthesized by a nanocasting route for high hydrogen sensing performance. Sens. Actuators B Chem. 2011, 160, 604-608. [CrossRef]

30. Hayashi, M.; Hyodo, T.; Shimizu, Y.; Egashira, M. Effects of microstructure of mesoporous $\mathrm{SnO}_{2}$ powders on their $\mathrm{H}_{2}$ sensing properties. Sens. Actuators B Chem. 2009, 141, 465-470. [CrossRef]

31. Gong, J.; Chen, Q.; Fei, W.; Seal, S. Micromachined nanocrystalline $\mathrm{SnO}_{2}$ chenical gas sensors for electronic nose. Sens. Actuators B Chem. 2004, 102, 117-125. [CrossRef] 